\title{
VALUE CONTEXT OF THE FORMATION OF PERSONALITY SELF- ACTUALIZATION AND INFORMATION CULTURE
}

\author{
Oksana Filonenko ${ }^{1}$, Rostyslav Liashenko ${ }^{2}$ \\ ${ }^{I}$ Doctor of Pedagogical Sciences, Associate Professor, Associate Professor of the Department of Pedagogy \\ and Management of Education, Volodymyr Vynnychenko Central Ukrainian State Pedagogical University, \\ Kropyvnytskyi, Ukraine, e-mail: oksana.filonenko02@gmail.com, ORCID: https://orcid.org//0000-0003- \\ 4453-9887 \\ ${ }^{2}$ Candidate of Pedagogical Sciences, Senior Lecturer of the Department of Pedagogy and Management of \\ Education Volodymyr Vynnychenko Central Ukrainian State Pedagogical University, Kropyvnytskyi, Ukraine, \\ e-mail: r.ljashenko@gmail.com,ORCID: https://orcid.org/orcid.org/0000-0003-3554-8861
}

\begin{abstract}
Formation of personality self-actualization and information culture considered through the value context in the article. Based on the analysis of scientific literature it has been substantiated the formation of the information culture of the personality becomes one of the main tasks of social institutions of society, and the purpose of its formation is the socialization and acculturation of person in the new conditions of existence, which irretrievably change following the rapid development of information and communication technologies and based on their application all human spaces existence and activities. It has been concluded that the need for self-actualization self-develops along with the expansion of human knowledge about the world and about oneself, with the growth of subjective capabilities and the complexity of the tasks faced. The interdevelopmental relationship between the individual and society is achieved not only by overcoming negative and using positive individual assets, but due to the fact that society develops such individual characteristics that are due to social expectations, antipodes, values and only in harmony with them provide a high level of professional activity. It has been analyzed that as a product of the development of the information society, information culture is a broader concept than anthropogenic culture and includes all its main characteristics that do not contradict civilization development. At the same time there are new components serving informational culture patterns, which are characteristic only for the information society, which has been formed in general, and its information and communication technologies. It has been explained that in certain aspects the problem of self-actualization of the individual involves the development of tools and conditions that stimulate the processes of selfknowledge, goal-setting, designing prospects for individual life. The reason for self-actualization has been view as the need to reconcile the inner intentions of human and the conditions in which one lives.
\end{abstract}

Key words: development, information culture, personality, self-actualization, values.

JEL Classification: A22, I23

Formulas: 0; fig.: 0; tabl.: 0; bibl.: 20.

Introduction. In the process of developing one's activity, the individual actively searches, creates and transforms the conditions for meeting socially significant needs in accordance with one's personal position, values and requirements that apply. Understanding the phenomena of "self" of the individual can be based on a complex system of personality qualities, where attitudes, interests, worldview criteria and attitudes of the individual to social values on a single basis regulate one's spiritual and subject-practical activities.

Modern society cannot develop beyond the information, the level of development of which is often associated with the level of culture development, in which a person plays the role of a creator, a distributor and a keeper of information, realizing the model "person - information - person". Thus, a special feature of this society is the formation of a new image of society and the transformation of personality. In the information 
society, the process of forming a new person with one's own internal characteristics takes place, and this process can be characterized as the main socio-ontological search in modern conditions.

Literature Review. Scientific researches of recent years of such scientists as Bekh, I. D., Radul, V. V., Haleta, Y. V., Lebedyk, I. V., Lebedyk, M. P., Torbenko, I. O., Kharchenko, S. Ya., Yavorska, G. Kh. et al present particular interest for the study of education of values, aspects of self-education, problems of their social maturity, socialization, self-realization, and other phenomena of "self"; features of development of information culture of personality is in the field of vision of the following researchers: Jaspers, K., Atajan, A. M., Winner, N., Mamford, L., Rozin, V. M., Bodrijjar, Zh. V., Ovchinnikova, I. G., Pronina, L. A., Haleta, Y. V. et al.

In the middle of the twentieth century K. Jaspers noted that with the appearance of modern technology everything changed: it sharply increased social dynamics and became a fundamentally new factor in world history, which caused changes, not comparable to anything known to people in the last five thousand years [7].

The high dynamics of information processes in modern society implies the existence of a fundamental difference in the socialization of the individual, which should not occur in the conditions of a spontaneous impact of different circumstances of life and occasional factors of socialization (as in industrial society). Personality needs to be purposefully educated and trained for life in modern conditions [1].

Passive consumption of information through radio, telephone, audio, television, computer increasingly displaces active forms of creativity, leisure, knowledge, forms stiffness of thinking, deprives people of direct communication with each other.

"We changed our environment so radically, that now we have to change ourselves in order to exist in this environment," writes N. Winner [20, p. 43].

N. Winner noted, "all human social life in its normal manifestations is centered around the language. Language is the greatest interest of person and is the most characteristic achievement of the person "[20, p. 82].

The problem of personality self-actualization is an internal way of selfdevelopment, adequate for a person endowed with consciousness, so it is an immanent and invariant feature inherent in the whole nature, not just the nature of human. In our opinion, however there is a cultural and historical range within which the problem of self-actualization as a concomitant phenomenon, as a mandatory component of any interaction of the system with the environment becomes a problem of self-actualization as a conscious way of personality existence. Only in this case, self-realization and, accordingly, the problem of self-actualization start determining the personality lifestyle, and the multidimensional world of human becomes space for self-realization, self-realization and self-creation in its value coordinates", emphasizes Galazhinsky, Ye. V. [5, p. 41].

Dermanova, I. B. calls self-identification as one of the mechanisms of selfrealization [4], while special importance in personal identity, she gives to value orientations and considers moral self-identification as an effective mechanism for personality self-realization and self-actualization.

Aim. The purpose of the article is to analyze and substantiate formation of 
personality self-actualization and information culture considered through the context of values.

Methods. The development of society was relatively recently characterized as socio-cultural, but today it looks more like a technocratic one. Spiritual, intellectual potential of society is increasingly identified with information, causing changes in culture, language, and way of life and even in thinking. The information and knowledge of the individual began to substitute their knowledge, human abilities for understanding and solving problems.

It would be a simple utopia to ignore the development of technology and its effect on person and society as a whole, because it is a material means of human activity, and, consequently, of culture. One can agree with V. M. Rosin, when he writes, that human activity has two components: acts of activity that are realized on a rationalization basis, and cultural components that live by another logic. Therefore, he concludes that most of the problems that arise in society today cannot be solved by a scientific and technical method [15].

J. Bodrijjar, studying the problems of the information society, believed that modern culture is a culture of signs. However, signs simulate reality instead of reflecting it. Modern society, according to J. Bodrijjar, is filled with signs. Every day, mass communication brings to a consumer a huge amount of facts and their interpretations. Consciousness is split because one cannot understand all of this and distinguish between one's own desires from others [3]. Therefore, it is now very urgent to analyze positive and negative aspects of adaptation process.

We share A. D. Toynbee's point of view, who revealed the logical connection between the development of personality and society. He stated that a person acquires the opportunity to perform creative acts that determines the development of society itself precisely due to the internal development of a person. The transitional stage of the bifurcation point in the development of humankind has come: the stage of selfdevelopment of the individual, their ability to create the new. This is the stage of personal creativity, which is determined by the maturity of the person oneself, as well as the development of society.

Because of the information and communication technologies use, global changes in culture - processes of dialogue and interpenetration of cultures are taking place.

In the analysis of these changes, philosophy, cultural science uses concepts such as "traditional culture", "technogenic culture", "information culture", "computer culture," often not revealing them, not explaining the relationship between these concepts, the extent of their entry into the concept of modern culture, their role in its formation. These concepts are used not only in philosophy, but also in other branches of knowledge, for example, in pedagogy, where they acquire a different meaning.

Self-realization is associated with the development of criteria for evaluating achievements, with the desire for a moral ideal, with the intention to embody in their own behavior their ideas about the personality values. In fact, it is about defining oneself in the social world. "I am responsible for myself and for all," wrote J.-P. Sartre, "and I create an image of human that corresponds to my idea of what a person should be" [16, p.165]. 
Self-realization as a process of self-realization is the "realization of oneself" in life and everyday activity, the search for and affirmation of one's special way in this world, one's values and the meaning of one's existence at any time. Self-realization occurs when a person has a strong excitation motive for personal growth "[8, p. 52].

Results. The formation of a culture of a new social formation in the conditions of global processes of informatization becomes the object of the analysis of philosophy, culture studies. The notion of information culture is considered as "a branch of culture associated with the functioning of information in society and the formation of information qualities of the individual" [19, p. 57]; "a qualitative characteristic of human life in the field of receiving, transmitting, storing and using information, where universal human values are a priority" [18, p. 28]; "a level of knowledge that allows a person to freely navigate in the information space, participate in its formation and promote information interaction" [9, p. 59]; "a measure of person's, a society's or a certain part of one's perfection in all possible kinds of work with information: its receiving, accumulation, coding and processing of any kind, in creating on this basis qualitatively new information, its transmission, practical use" [17, p. 3], etc.

Based on the analysis of these and many other similar definitions, we can conclude that this concept is interpreted as a person's information culture, adaptive mechanism of its existence in the information society. At the same time, the formation of the information culture of the individual becomes one of the main tasks of social institutions of society, and the purpose of its formation is the socialization and acculturation of person in the new conditions of existence, which irretrievably change following the rapid development of information and communication technologies and based on their application all human spaces existence and activities without exception.

However, the information culture in the modern information society should be considered not only as a measure of the formation of a person for the organic entry into the information society, the space of culture of this society, but also as the level of organization of information processes; measure of satisfaction of people with information communication; the level of effectiveness of creating, collecting, storing, processing, transmitting, presenting and using information that provides a coherent picture of the world, prediction of the consequences of the decisions taken. As a product of the development of the information society, information culture is a broader concept than anthropogenic culture and includes all its main characteristics that do not contradict civilization development. At the same time there are new components serving informational culture patterns, which are characteristic only for the information society, which has been formed in general, and its information and communication technologies (communication and interpersonal communication, information security, sphere of information services, etc.).

V. K. Beloshapka proves that for every existing object in the world one can look at three fundamental points of view, according to the triad "matter-energyinformation". The author emphasizes the main, dominant nature of the information aspect, noting that the information point of view on the world did not appear in connection with the invention of the computer: "the information point of view at all can hardly be recognized fundamentally new. Such views were not foreign to either a 
new time or middle ages, nor antiquity. Nevertheless, if we should see all these features of the system-information point of view in the past, then only in the germinal or immature form. Language, if you will, about the knowledge of the world of person, on the degree of maturity of this knowledge" [2, p. 4].

In research, socialization is often considered successful if personality learns the right social roles, accepted in this society system of values, social norms and productive stereotypes of behavior [10].

Some scholars argue that personal activity "expresses the level of realization of functional features of social community, the level of general sociality of the personality, one's internal need, the level of acceptance of society's values..." [11, p. $6]$.

In the center of the pedagogical concept of self-realization and self-actualization there is the belief in individual experience of a person and one's ability to selfrevelation, the ability to reveal in oneself express a unique and unrepeatable essence, in determining the direction and means of personal growth. Here the impact of socioprofessional requirements is carried out on self-esteem, self-affirmation, selfdetermination, professional self-awareness, motivation for achievement in the profession, the goal of professional growth. The reason for self-actualization is the need to reconcile the inner intentions of human and the conditions in which one lives. The pedagogical aspect of the problem of personality self-actualization involves the development of tools and conditions that stimulate the processes of self-knowledge, goal-setting, designing prospects for individual life.

The pedagogical approach to explaining the development of professional selfactualization of the individual explains the hierarchy of activities that at successively changing stages of ontogenesis are leading to the successful solution of vocational education.

Discussion. In modern conditions, creation of a developed mechanism of selfregulation of society, capable of identifying, anticipating crisis situations, exacerbating social contradictions and problems, tendencies of counteraction and inhibition, and solving them, based on the principles and regularities of the information society, is needed. According to L. O. Pronina, such a mechanism of social evolution, which provides self-regulation and self-government of political, ideological, informational and public subsystems, is an information culture. Information culture promotes real understanding of the person oneself, their place and role in the world surrounding them, history, system of modern world connections [13].

Thus, the system-information point of view of a person on the world or the foundations formation of one's information culture, testifies to the degree of person's maturity.

The concept of culture characterizes a certain degree of maturity of society and person. Even the ancient Greeks, the creators of high cultural standards, that today act as aesthetic ideals, have created a system of education that aspired not only to professionalism in any field, but also focused on the formation of a person's personality with value orientations and worldview. 
Interaction of informational culture and maturity of a person was distinguished by I. G. Ovchinnikov. In scientist's opinion, the information culture of someone studying in the system of continuous education has a wider significance. It contributes at the pre-university level to an increase in the level of educational readiness, social selfdetermination (educational maturity). At the higher level - it promotes readiness for professional activity, professional self-determination (academic maturity). At the postgraduate stage - determines readiness to improve professional skills and career development (professional maturity) [12].

According to Haleta Y. V. mastering information culture is a way to universalize human qualities, which contributes to a person's real understanding of oneself, one's place in life. An important role in the formation of information culture is played by education, which should prepare a specialist for the information community, developing one's skills and abilities: differentiation of information; selection of significant information; establishing criteria for evaluating information; creation of information and its use [6, p. 50].

Summing up the variety understanding of the content of "personality's social maturity" phenomenon V. V. Radul notes that "a person is the subject of human activity, which in one's turn is aimed at transforming the surrounding reality" [14, p. 25-26]. Every person acquires specific historical forms and ways of knowing the world and thus forms an individual, unique personality in the cultural sense, formed by one's own life experience and a way of one's knowledge [14, p. 26].

Conclusion. The need for self-actualization and other phenomena "self" develops along with the expansion of human knowledge about the world and about oneself, with the growth of subjective capabilities and the complexity of the tasks human faces.

Any other human activity by its nature is predominantly communicative, such that involves the exchange of essential meanings, spiritual values between people. Communication is a condition of human existence, society, a special type of their interaction, which is formed in the process of cultural development in connection with the need to transmit information in time and space through special sign systems.

The interdevelopmental relationship between personality and society is achieved not only by overcoming negative and using positive individual assets, but due to the fact that in the society develops such individual characteristics that are due to social expectations, antipodes, values and only in harmony with them provide a high level of professional activity.

Author contributions. The authors contributed equally.

Disclosure statement. The authors do not have any conflict of interest.

\section{References:}

1. Atajan, A. M. (2001), Informacionnaja kul'tura lichnosti v uslovijah informatizacii obshhestva [Personality Information Culture in the Conditions of Society's Informatization]. VIU Bulletin. No1(7). Retrieved from http://www.viunline.ru/ science/publ/bulletin7/ page9.html. [in Russian].

2. Beloshapka, V. K. (1988), Mir kak informacionnaja struktura [World As An Information Structure]. Informatika i obrazovanie [Computer science and education]. No 5. [in Russian].

3. Bodrijjar, Zh. V. (2000), Teni molchalivogo bol'shinstva, ili Konec social'nogo [The Shadows of the Silent Majority, or the End of the Social ]. Ekaterinburg. Ural u-ty Publishing. [in Russian].

4. Dermanova, I. B. (1999), Nravstvennaja samoidentifikacija kak reguljator motivov povedenija [Moral selfidentification as a regulator of motives of behavior]. Psychological conditions of self-realization of the person, Issue. 3 . [Ed. L.A. Golovey, L.A. Korostyleva]. St. Petersburg. [in Russian]. 
5. Galazhinsky, Ye. B. (2002), Sistemnaja determinacija samorealizacii lichnosti: Diss. ... d-ra psihol. nauk [Systemic determination of personality self-realization. Thesis Synopsis For Obtaining Doct. of Psychol. Sciences Degree]. Tomsk. [in Russian].

6. Haleta Y. V. (2011), Informatsiina kultura v profesiinii pidhotovtsi maibutnoho pedahoha [Information culture in the professional training of future teachers], Ridna Shkola, №11 [in Ukrainian].

7. Jaspers, K. (1986), Sovremennaja tehnika [Modern technology]. Novaja tehnokraticheskaja volna na Zapade [New Technocratic Wave in the West]. Moscow. [in Russian].

8. Leontiev, D. A. (1997), Samorealizacija i sushhnostnye sily cheloveka [Self-realization and the essential forces of human]. Psychology with a human face: a humanistic perspective in post-Soviet psychology [Ed. D.A. Leontiev, V.G. Rat]. M. [in Russian].

9. Medvedeva, E. A. (1994), Osnovy informacionnoj kul'tury [Basics of Information Culture]. Socis. No 11. [in Russian]. 10. Mudrik, A. V. (1991), Koncepcija vospitanija uchashhejsja molodezhi v sovremennom obshhestve [The concept of educating young students in modern society] [A. V. Mudrik, A. A. Bodalev, Z. A. Malkova]. M. [in Russian].

11. Novikov, B. V. (1989), Social'naja aktivnost' kak mera samodejatel'nosti lichnosti [Social activity as a measure of selfactivity]. Creativity and philosophy. K. [in Russian].

12. Ovchinnikova, I. G. (2009), Razvitie informacionnoj kul'tury obuchajushhihsja v sisteme nepreryvnogo obrazovanija [Development of Students' Information Culture in the System of Continuous Education]. avtoref. dis. d-ra ped. nauk : 13.00.01 [Thesis Synopsis For Obtaining Doct. of Ped.Sc.Degree. 13.00.01 specialty]. Magnitogorsk. [in Russian].

13. Pronina, L. A. (2008), Informacionnaja kul'tura kak faktor razvitija informacionnogo obshhestva [Information Culture as a Factor of the Information Society Development]. Analitika kul'turologii [Cultural Analytics]. No 10. Retrieved from http://cyberleninka.ru/article/n/informatsionnaya-kultura-kak-faktor-razvitiya-informat sionno go-obschestva. [in Russian].

14. Radul, V. V. (2017), Social'na zrilist' osobistosti [Personality’s Social Maturity]. Harkiv. Machulin. [in Ukrainian].

15. Rozin, V. M. (2006), Ponjatie i sovremennye koncepcii tehniki [Definition and Modern Concepts of Technology]. Moscow. IF RAN. [in Russian].

16. Sartre, J. -P. (2000), Bytie i nichto. Opyt fenomenologicheskoj ontologii [Being and nothing. Experience of phenomenological ontology]. Moscow. Progress. [in Russian].

17. Semenjuk, Je. L. (1994), Informacionnaja kul'tura obshhestva i progress informatiki [Information Culture of Society and the Progress of Computer Science]. NTI. Ser. 1. No 7. [in Russian].

18. Uebster, F (2004), Teorii informacionnogo obshhestva [Theories of the Information Society]. Moscow. Aspekt Press. [in Russian].

19. Vohrysheva, M. G. (1997), Formirovanie nauki ob informacionnoj kul'ture [Formation of Information Culture Science]. Problemy informacionnoj kul'tury [Information Culture Problems]. Moscow. Magnitogorsk. Issue 6. [in Russian].

20. Winner, N. (1983), Kibernetika, ili Upravlenie i svjaz' v zhivotnom i mashine [Cybernetics, or Control and Communication in the Animal and the Machine] Moscow. Nauka. [in Russian]. 